\title{
MODEL PENGELOLAAN BISNIS OBYEK WISATA HIDDEN CANYON DI BALI BERBASIS KEARIFAN LOKAL TRI HITA KARANA DAN SUSTAINABILITY
}

\author{
Komang Aris Raharja ${ }^{1^{*}}$, Luh Putu Mahyuni \\ ${ }^{1}$ Fakultas Ekonomi dan Bisnis, Universitas Pendidikan Nasional \\ Email: arisraharja@gmail.com \\ ${ }^{2}$ Fakultas Ekonomi dan Bisnis, Universitas Pendidikan Nasional \\ Email: mahyuniluhputu@undiknas.ac.id \\ *penulis korespondensi
}

Masuk : 08-09-2021, revisi: 08-10-2021, diterima untuk diterbitkan : 10-10-2021

\begin{abstract}
ABSTRAK
Penelitian ini bertujuan untuk mengeksplorasi pengelolaan obyek wisata Hidden Canyon berbasis nilai kearifan lokal tri hita karana dan prinsip sustainability. Penelitian ini menggunakan pendekatan kualitatif dengan mengumpulkan data melalui wawancara dan studi dokumentasi. Penelitian ini dilakukan di Obyek Wisata Hidden Canyon, Beji Guwang, Kabupaten Gianyar, Bali. Penelitian ini menemukan bahwa obyek wisata Hidden Canyon menerapkan model pengelolaan berbasis prinsip tri hita karana yang selaras dengan prinsip sustainability. Penelitian ini secara umum menemukan bahwa pengelola obyek wisata Hidden Canyon dalam pengelolaannya memperhatikan keselaran antara upaya pengembangan bisnis dan ekonomi masyarakat sekitar dengan upaya pelestarian lingkungan dan kepedulian sosial. Pengelola secara intens melakukan upaya pemberdayaan masyarakat, peningkatan daya tarik obyek wisata, dan memfasilitasi wirausaha lokal. Upaya pelestarian lingkungan dilakukan melalui kampanye anti sampah plastik dan menjaga saluran air subak. Pengelola obyek wisata juga secara aktif memberikan bantuan sosial tunai dan keagamaan kepada desa adat.
\end{abstract}

Kata Kunci: Pengelolaan Obyek Wisata Alam, Sustainability, Sustainable Tourism, Tri Hita Karana

\begin{abstract}
This study aims to explore the management of Hidden Canyon tourism objects based on the value of tri hita karana local wisdom and the principle of sustainability. This study uses a qualitative approach by collecting data through interviews and documentation studies. This research was conducted at Hidden Canyon Tourism Object, Beji Guwang, Gianyar Regency, Bali. This study found that the Hidden Canyon tourism object applies a management model based on the tri hita karana principle which is in line with the principle of sustainability. This research generally finds that the manager of the Hidden Canyon tourism object in achieving business and economic development goals pays attention to environmental conservation and social care efforts. The manager intensively makes efforts to empower the community, increase the attractiveness of tourism objects, and facilitate local entrepreneurs. Efforts to preserve the environment are carried out through anti-plastic waste campaigns and maintaining subak waterways. Tourism object managers also actively provide cash for villagers' religious and social activities.
\end{abstract}

Keywords: Management of Natural Tourism Objects, Sustainability, Sustainable Tourism, Tri Hita Karana

\section{PENDAhUluAN \\ Latar Belakang}

Industri pariwisata memiliki peran penting dalam menyerap tenaga kerja, meningkatkan perekonomian masyarakat dan sebagai salah satu sumber devisa negara. Industri pariwisata Indonesia mempekerjakan lebih dari 13 juta tenaga kerja, jumlah ini meliputi 10,28\% total tenaga kerja Indonesia (Kemenpar, 2020). Salah satu komponen penting industri pariwisata adalah destinasi wisata. Indonesia memiliki cukup banyak destinasi wisata yang menarik untuk dikunjungi, begitupula Bali. Destinasi wisata di Bali yang banyak dikunjungi antara lain pantai, gunung, desa-desa, hutan. Beberapa faktor penunjang daya tarik destinasi wisata antara lain keamanan, keunikan seni dan budaya Bali, serta fasilitas lengkap sarana pariwisata. 
Kehidupan masyarakat di Bali yang begitu kental dengan nilai religius menjadikan berbagai obyek wisata di Bali memiliki daya tarik tersendiri. Akan tetapi, tanpa pengelolaan yang baik, keberlangsungan industri pariwisata dalam jangka panjang akan terancam. Dalam kaitan ini, penerapan konsep pembangunan berkelanjutan (sustainable development) dalam pengelolaan obyek wisata sangatlah penting. Sustainable development atau pembangunan berkelanjutan adalah konsep pembangunan yang memperhatikan kemampuan generasi mendatang untuk memenuhi kebutuhan mereka (Hajian \& Jangchi Kashani, 2021). Pariwisata dalam hal ini juga memerlukan pola pembangunan berkelanjutan (Sustainable Tourism Development) untuk dapat memberikan manfaat ekonomi bagi masyarakat dan pada saat yang bersamaan menjaga keberlangsungan sumber daya alam dan sosial budaya.

Proses pembangunan pariwisata berkelanjutan (Sustainable Tourism Development), khususnya di Bali diaplikasikan dengan menerapkan nilai kearifan lokal, yaitu tri hita karana (Juniari \& Mahyuni., 2020; Mahyuni \& Dewi, 2021). Tri hita karana bermakna tiga sumber kebahagiaan, yaitu dari upaya menjaga kedekatan dengan Sang Pencipta-Parahyangan; menjaga keharmonisan hubungan dengan sesama-Pawongan; dan menjaga relasi yang harmonis dengan alam-Palemahan (Krishna, 2010). Inti filosofi tri hita karana ini selaras dengan prinsip pembangunan berkelanjutan yaitu, menjaga keselarasan aspek sosial - budaya, lingkungan alam, dan ekonomi.

Laksana (2020) dan Wisnawa et al. (2019) menjelaskan bahwa suatu obyek wisata harus memiliki daya tarik sebagai alasan wisatawan untuk berkunjung, sehingga nantinya dapat dikembangkan secara berkelanjutan. Komponen pembentuk daya tarik wisata antara lain: 1. Atraksi, yaitu daya tarik suatu destinasi wisata seperti kesenian, budaya, kehidupan sosial, sumber daya alam dan aktivitas kegiatan yang dilakukan wisatawan; 2. Aksesibilitas, yaitu sarana dan prasarana seperti infrastruktur untuk mempermudah wisatawan mencapai destinasi wisata; 3. Amenitas, yaitu fasilitas pendukung seperti toilet, lahan parkir, dan sebagainya agar wisatawan merasa nyaman ketika berkunjung; dan 4. Ancillary, yaitu kelembagaan yang mengelola suatu destinasi wisata.

Obyek wisata di Bali tersebar di seluruh Kabupaten/Kota, salah satunya Kabupaten Gianyar. Kabupaten Gianyar dijuluki sebagai kota seni dan memiliki cukup banyak destinasi wisata menarik. Salah satu destinasi wisata yang dimiliki adalah obyek wisata Hidden Canyon Beji Guwang. Lokasi Hidden Canyon ini berada di wilayah Gianyar Selatan, yaitu di Desa Guwang, Kecamatan Sukawati yang merupakan salah satu destinasi wisata yang banyak diminati wisatawan. Data pengunjung obyek wisata Hidden Canyon yang diperoleh dari Kantor Pengelolaan Obyek Wisata Hidden Canyon (2020) menunjukkan trend peningkatan pada periode 2017 hingga 2019. Jumlah kunjungan wisatawan pada tahun 2017 - 2018 sebanyak 513 orang, dan pada periode 2018 - 2019 meningkat menjadi 778 orang.

Obyek wisata jika tidak dikelola dengan baik maka lambat laun akan mengancam keberlangsungannya. Diperlukan model pengelolaan agar keberlangsungan obyek wisata tersebut tetap terjaga. Menurut Pratiwi et al. (2018) pembangunan berkelanjutan merupakan perspektif baru pembangunan yang berkomitmen memberikan kontribusi untuk masa depan. Adanya peningkatan kunjungan wisatawan tentunya harus diimbangi dengan pengelolaan dan pengembangan. Permasalahan yang ada saat ini pada obyek wisata Hidden Canyon, yaitu kurangnya fasilitas umum dan akses yang kurang memadai, sehingga membuat wisatawan merasa tidak nyaman ketika berkunjung. Saat ini terdapat beberapa titik akses yang licin, kurangnya restaurant, dan ATM, hal tersebut tentu dapat mengurangi minat wisatawan untuk berkunjung. Selain itu, sebagai obyek wisata yang relatif baru dikembangkan, keterlibatan dan dampak bagi masyarakat belum optimal, begitupula dengan dampaknya bagi upaya pelestarian lingkungan alam di sekitar obyek wisata. 
Masih diperlukan upaya perbaikan pengelolaan obyek wisata dengan mengaplikasikan tata kelola berbasis sustainability.

\section{Rumusan Masalah}

Berdasarkan latar belakang yang telah diuraikan, yang menjadi pokok permasalahan dalam penelitian ini adalah: Bagaimana model bisnis pengelolaan obyek wisata Hidden Canyon di Bali berbasis kearifan lokal Tri Hita Karana dan sustainability?

\section{Kajian Literatur}

Manajemen obyek wisata adalah proses pengelolaan suatu sumber daya wisata yang dilakukan oleh suatu kelompok organisasi sehingga mempunyai daya tarik wisatawan untuk dikunjungi. Alfiah et al. (2019) menjelaskan jika pengelola wisata dengan objek wisata saling berkaitan dan sangat menentukan dalam kemajuan daerah wisata tersebut.

Sustainable development atau pembangunan berkelanjutan adalah sebuah konsep yang bertujuan untuk menciptakan keseimbangan dalam dimensi pembangunan, ekonomi, sosial dan budaya serta lingkungan. Sustainable development merupakan proses pembangunan yang mempunyai prinsip memenuhi kebutuhan saat ini tanpa mengorbankan pemenuhan kebutuhan generasi yang akan mendatang. Menurut Undang-Undang Nomor 32 Tahun 2009 tentang perlindungan dan pengelolaan lingkungan hidup, pembangunan berkelanjutan diartikan sebagai upaya sadar dan terencana yang memadukan aspek lingkungan hidup, sosial dan ekonomi ke dalam strategi pembangunan untuk menjamin keutuhan lingkungan hidup serta keselamatan, kemampuan, kesejahteraan dan mutu hidup generasi masa kini dan generasi masa depan. Pembangunan berkelanjutan bertujuan untuk meningkatkan kesejahteraan masyarakat, untuk memenuhi kebutuhan dan aspirasi manusia. Menurut Rosana (2018), pembangunan berkelanjutan merupakan wawasan lingkungan yang mampu meningkatkan mutu hidup generasi masa sekarang dan masa depan. Sementara Fauzi \& Oxtavianus (2014) menjelaskan bahwa konsep keberlanjutan ini paling tidak mengandung dua dimensi: Pertama adalah dimensi waktu, karena keberlanjutan tidak lain menyangkut apa yang akan terjadi di masa yang akan datang; Kedua adalah dimensi interaksi antara sistem ekonomi dan sistem sumber daya alam dan lingkungan.

World Tourism Organization (WTO) mendefinisikan pembangunan pariwisata berkelanjutan sebagai pembangunan yang memenuhi kebutuhan wisatawan saat ini, sambil melindungi dan mendorong kesempatan untuk waktu yang akan datang. Lebih lanjut Kristiana (2019) menjelaskan bahwa pembangunan pariwisata berkelanjutan dikembangkan untuk memenuhi kebutuhan wisatawan, industri pariwisata dan kebutuhan masyarakat lokal saat ini tanpa mengorbankan kemampuan generasi yang akan datang untuk memenuhi kebutuhannya sendiri. Menurut Kurniawati (2013) pembangunan pariwisata yang berkelanjutan dapat dikenali melalui prinsipprinsipnya yang dielaborasi berikut ini. Prinsip-prinsip tersebut antara lain: (1) Partisipasi; (2) Keikutansertaan para pelaku; (3) Kepemilikan lokal; (4) Penggunaan sumber daya yang berkelanjutan; (5) Mewadahi tujuan-tujuan masyarakat; (6) Daya dukung; (7) Monitor dan evaluasi; (8) Akuntabilitas; (9) Pelatihan; dan (10) Promosi. Dengan demikian dapat disimpulkan bahwa pembangunan pariwisata berkelanjutan dalam tujuannya harus menganut tiga prinsip dasar, yaitu: (1) Kelangsungan ekologi; (2) Kelangsungan sosial budaya; dan (3) Kelangsungan ekonomi.

Untuk menjaga keberlangsungannya, obyek wisata memerlukan model pengembangan pariwisata berkelanjutan atau sustainable tourism development. Pembangunan pariwisata berkelanjutan memiliki beberapa tujuan sebagai berikut: 1. Untuk membangun kesadaran yang semakin tinggi bahwa pariwisata dapat berkontribusi secara signifikan bagi pelestarian lingkungan dan 
pembangunan ekonomi; 2. Untuk meningkatkan keseimbangan dalam pembangunan; dan 3. Untuk meningkatkan kualitas pengalaman bagi masyarakat setempat.

Haryanto (2014) mengusulkan model pengembangan pariwisata berkelanjutan yang dibangun dari 4 aspek, yaitu: 1. Elemen utama (menjadikan isu pembangunan berkelanjutan sebagai visi dan tujuan utama dari pengelolaan wisata); 2. Elemen produk pariwisata (membentuk wisata yang berbasis masyarakat); 3. Elemen kriteria (memiliki pilar pelestarian lingkungan, budaya, pengayaan atraksi, pendidikan berbasis partisipasi, keeratan masyarakat, dan pemberdayaan ekonomi masyarakat lokal); 4. Elemen pendukung (mendukung sepenuhnya seluruh stakeholders baik masyarakat, pengunjung, pengelola, perguruan tinggi, pemerintah pusat, pemerintah daerah maupun pengusaha pariwisata sebagai elemen pendukung).

Pengembangan model pengelolaan obyek wisata berbasis prinsip keberlanjutan dan kearifan lokal menjadi semakin vital mengingat cukup besarnya dampak negatif yang ditimbulkan akibat pengelolaan yang serampangan. Menurut Putra \& Putra (2019), dampak negatif pengelolaan obyek wisata yang tidak memperhatikan prinsip keberlanjutan antara lain berupa pelunturan budaya lokal masyarakat dan hilangnya norma-norma di masyarakat, pencemaran lingkungan, dan alih fungsi lahan besar-besaran sehingga menyebabkan rusaknya struktur lingkungan sekitar. Selain itu, jika ditinjau dari aspek bisnis dan ekonomi, pengelolaan obyek wisata yang tidak memperhatikan prinsip keberlajutan akan berisiko ditinggalkan wisatawan.

Sebaliknya, pengelolaan obyek wisata secara optimal berbasis prinsip keberlanjutan dan kearifan lokal, akan mampu meningkatkan daya tariknya dan tentu saja meningkatkan jumlah kunjungan wisatawan, hal ini telah dibuktikan oleh beberapa penelitian sebelumnya, antara lain penelitian oleh Gautama \& Sunarta (2016); Sumaeni \& Mahagangga (2018); dan Hidayat (2011). Lebih lanjut, menurut Arimbawa \& Santhyasa (2012) dan Lestari et al. (2017), penerapan nilai-nilai kearifan lokal dalam proses pengelolaan obyek wisata menghasilkan kesuksesan destinasi wisata dalam mempertahankan dan melestarikan sumber daya lokal.

Penelitian oleh Anggreswari \& Jayaningsih (2018) serta Apriyani (2016) menemukan dampak positif pengelolaan obyek wisata berbasis masyarakat bagi upaya penyerapan tenaga kerja lokal. Yachya et al. (2016) menemukan hal serupa, pengelolaan obyek wisata berbasis masyarakat dan nilai kearifan lokal mampu mengaktifkan potensi ekonomi dan mengintegrasikan masyarakat sekitar dalam memperoleh keuntungan ekonomis dengan adanya pengelolaan obyek wisata. Dewi et al. (2013) menyarankan perlunya dukungan pemerintah daerah sebagai fasilitator bagi terwujudnya kemandirian masyarakat dalam mengelola obyek wisata, bagi tercapainya tingkat kesejahteraan masyarakat yang lebih baik.

Menurut Novarini \& Anggraini (2017), terdapat beberapa aspek yang perlu diperhatikan dalam pengelolaan obyek wisata berbasis kearifan lokal dan keberlanjutan, antara lain aspek kualitas layanan, citra, dan promosi yang dapat mempengaruhi tingkat kepuasan pengunjung pada suatu obyek wisata. Mahadewi \& Sudana (2017) menjelaskan pentingnya aspek destinasi, industri, kelembagaan, dan pemasaran dalam pengelolaan obyek wisata. Strategi komunikasi pemasaran yang dapat diterapkan, menurut Sembiring (2016) dapat dalam bentuk informatif, edukatif, dan persuasif.

Minimnya kegiatan pemasaran dan relatif rendahnya kemampuan pengelola obyek wisata di Indonesia dalam menerapkan strategi pemasaran yang tepat, ditemukan sebagai permasalahan umum yang sering dihadapi pengelola obyek wisata di Indonesia, menurut Al-Bakry (2013). Hal 
ini menjadi salah satu faktor penjelas sulit berkembangnya suatu bisnis obyek wisata. Untuk dapat menerapkan strategi pengelolaan dan pemasaran yang tepat, pemahaman akan aspek psikologis wisatawan sangatlah penting, seperti faktor yang menjelaskan minatnya untuk mengunjungi suatu obyek wisata. Pemahaman yang baik akan aspek psikologis wisatawan dapat membantu pengelola obyek wisata dalam merancang obyek wisata agar dapat memenuhi ekspektasi wisatawan

Penelitian sebelumnya (Haddouche \& Salomone, 2018; Mahyuni, Permana, et al., 2020; Mahyuni, Yoga, et al., 2020; Wiweka et al., 2019) telah mengidentifikasi beberapa faktor yang menjelaskan minat wisatawan mengunjungi suatu obyek wisata, khususnya obyek wisata alam/eco-park. Faktor-faktor tersebut antara lain: persepsi positif akan suatu obyek wisata (bentang alam yang indah dan alami, udara segar, banyak alternatif aktivitas alam terbuka yang dapat dilakukan, banyak spot foto menarik), pengaruh ajakan/referensi teman dekat dan keluarga, pengaruh review/rating pengunjung, ketersediaan informasi yang menarik terkait obyek wisata di internet, dan akses menuju obyek wisata.

\section{METODE PENELITIAN}

Penelitian ini dilakukan di Obyek Wisata Hidden Canyon, Desa Guwang, Kabupaten Gianyar, Provinsi Bali. Jenis data yang digunakan dalam penelitian ini adalah data kualitatif. Metode ini digunakan karena tujuan dari penelitian ini yaitu untuk mengeksplorasi model pengelolaan obyek wisata Hidden Canyon berbasis nilai kearifan lokal tri hita karana dan sustainability. Penelitian ini menggunakan data primer yang diperoleh dari beberapa narasumber melalui proses wawancara mendalam dan data sekunder yang diperoleh dari dokumen pengelola dan tangkapan layar akun media sosial pengelola. Informan yang digunakan dalam penelitian ini dipilih secara purposive, yaitu Perbekel/Kepala Desa Guwang, pengelola, pemandu wisata, dan pedagang.

Instrumen yang digunakan dalam penelitian ini berupa pedoman wawancara, alat perekam suara untuk merekam wawancara, buku catatan yang digunakan untuk mencatat hasil wawancara. Teknik pengumpulan data yang digunakan adalah wawancara mendalam untuk memperoleh informasi mengenai model pengelolaan obyek wisata Hidden Canyon berbasis nilai kearifan lokal tri hita karana dan sustainability. Teknik analisis data yang digunakan antara lain dengan cara reduksi data, penyajian data, verifikasi data, dan penarikan kesimpulan. Teknik pemeriksaan keabsahan data yang digunakan adalah triangulasi sumber (mendapatkan data dari berbagai sumber berbeda) dan triangulasi teknik (membandingkan data hasil wawancara dengan dokumen yang relevan) .

\section{HASIL DAN PEMBAHASAN}

Wawancara dilakukan kepada empat narasumber dengan waktu, tempat dan durasi yang berbedabeda antara lain pihak pengelola Hidden Canyon, perbekel/kepala desa Guwang, pemandu obyek wisata Hidden Canyon, dan pedagang di obyek wisata Hidden Canyon. Wawancara direkam menggunakan alat perekam setelah itu hasil wawancara diubah dalam bentuk transkrip. Masingmasing transkrip dibaca secara menyeluruh untuk kemudian dilakukan peringkasan data dengan cara mengidentifikasi pokok-pokok bahasan penting yang akan disajikan dan dianalisis lebih jauh. Beberapa kutipan wawancara penting yang dapat mewakili pokok-pokok bahasan yang teridentifikasi ditampilkan sebagai data pendukung pokok bahasan yang dipaparkan. Untuk memudahkan proses penyajian data maka informan diberikan kode sebagai berikut: pengelola obyek wisata (I1), kepala desa (I2), pemandu wisata (I3), pedagang di sekitar obyek wisata (I4). 


\section{Hasil Penelitian}

Secara umum penelitian ini menemukan bahwa pengelolaan obyek wisata Hidden Canyon dilakukan dengan berlandaskan pada prinsip tri hita karana dan sustainability, yang terdiri dari tiga pilar utama, yaitu ekonomi, sosial budaya, dan ekologi. Lebih lanjut, penelitian ini secara umum menemukan tiga tema utama, yang pertama adalah tema peningkatan ekonomi, kedua adalah tema kepedulian sosial, dan ketiga adalah tema pelestarian lingkungan. Tema peningkatan ekonomi terdiri dari tiga pokok bahasan/kode, yaitu pemberdayaan masyarakat, strategi peningkatan daya tarik obyek wisata, dan memfasilitasi wirausaha lokal. Tema kepedulian sosial terdiri dari dua kode yaitu bantuan sosial tunai kepada desa adat dan bantuan dana keagamaan. Tema pelestarian lingkungan terdiri dari dua kode yaitu kampanye anti sampah plastik dan menjaga saluran air subak. Berikut adalah penjelasan secara detail untuk masing-masing tema dan kode.

\section{Peningkatan Ekonomi}

Secara umum terdapat tiga kode utama yang diidentifikasi terkait peningkatan ekonomi di Desa Guwang, yaitu pemberdayaan masyarakat, strategi peningkatan daya tarik obyek wisata, dan memfasilitasi wirausaha lokal.

1. Pemberdayaan Masyarakat

Berdasarkan hasil wawancara ditemukan fakta bahwa pengelola Hidden Canyon berusaha untuk melibatkan seluruh masyarakat lokal dalam pengelolaan obyek wisata sebagaimana dinyatakan oleh I1 yang didukung pula oleh pernyataan I2 dan I3 sebagai berikut "Tenaga yang kita gunakan adalah semua dari masyarakat lokal disini" (I1). "Untuk masyarakat saya pikir sih sudah ya karena dilihat dari karyawan disana, semua merupakan warga disini" (I2). "Petani yang tanahnya dipakai untuk jalan nike dibayar 350 ribu perbulan" (I3).

2. Strategi Peningkatan Daya Tarik Obyek Wisata

Berdasarkan hasil wawancara ditemukan fakta bahwa pengelola Hidden Canyon telah memiliki strategi dalam meningkatkan daya tarik obyek wisata Hidden Canyon yang bertujuan untuk meningkatkan profit dari obyek wisata Hidden Canyon sebagaimana dinyatakan oleh I1 dan I2 sebagai berikut, "Membuat atraksi swing disamping swing kita akan membangun resto dan memanfaatkan bangunan yang kosong ini untuk menjadi sebuah tempat atraksi nah kita sudah punya program nah kebetulan disini juga sudah ada seka barong, kecak nanti ini akan kita kedepannya akan kita manfaatkan untuk stage barong dan kecak" (I1). "Untuk pengembangan obyek wisata yaitu swing kemungkinan setelah pembangunan swing kita akan merencanakan untuk pembangunan restoran” (I2).

3. Memfasilitasi Wirausaha Lokal

Berdasarkan hasil wawancara ditemukan fakta bahwa pihak pengelola Hidden Canyon memfasilitasi wirausaha lokal untuk dapat berjualan disekitar lokasi obyek wisata Hidden Canyon tanpa dikenakan biaya sewa, sebagaimana dinyatakan oleh I1 dan I3 sebagai berikut, "Kita membuka peluang usaha bagi setiap masyarakat yang ingin membuka usaha disini dan katakanlah tidak dikenakan sewa tempat" (I1). "Cuma yen membuka usaha dini to sing kena sewa bangunan" (I3).

\section{Kepedulian Sosial}

Secara umum terdapat dua kode utama yang diidentifikasi terkait kepedulian sosial yang dilakukan oleh pengelola Hidden Canyon kepada Desa Adat Guwang, yaitu bantuan sosial tunai kepada desa adat dan bantuan dana keagaman.

1. Bantuan Sosial Tunai Kepada Desa Adat

Berdasarkan hasil wawancara ditemukan fakta bahwa pihak pengelola Hidden Canyon memberi bantuan sosial tunai sebesar 300 juta rupiah pada tahun 2019 kepada desa adat Guwang sebagaimana dinyatakan oleh I1 dan I2 sebagai berikut "Sebagai timbal balik karena 
tanah ini milik desa adat jadi kita memberikan bantuan tunai sebesar 300 juta pada tahun 2019" (I1). "Sumbangan untuk.... istilahnya kegiatan masyarakat" (I2).

2. Bantuan Dana Keagaman

Berdasarkan hasil wawancara ditemukan fakta bahwa pihak pengelola Hidden Canyon memberikan bantuan dana keagamaan saat terdapat odalan/upacara keagamaan di pura yang berlokasi di desa Guwang sebagaimana dinyatakan oleh I1, I2, dan I3 sebagai berikut, "Jika ada odalan kita juga melakukan persembahyangan dan juga dana punia" (I1). "Di dana sosial yang kita gunakan melakukan sumbangan keagamaan" (I2). "Setiap ada odalan kita pasti sembahyang bersama dan juga menghaturkan punia" (I3).

\section{Kelestarian Lingkungan}

Secara umum terdapat dua kode utama yang diidentifikasi terkait kelestarian lingkungan yang dilakukan oleh pengelola Hidden Canyon kepada Desa Adat Guwang, yaitu kampanye anti sampah plastik dan menjaga saluran air subak.

1. Kampanye Anti Sampah Plastik

Berdasarkan hasil wawancara ditemukan fakta bahwa pihak pengelola Hidden Canyon melakukan kampanye anti sampah plastik untuk menjaga kelestarian lingkungan sebagaimana dinyatakan oleh I1 dan I2 sebagai berikut, "Salah satu konsen dari Hidden Canyon Beji Guwang ini adalah no plastic, nah sehingga semua yang kita lakukan kita tidak menyediakan plastik sama sekali" (I1). "Kita juga mengadakan bersih bersih lingkungan mengikuti gerakan anti sampah plastik nah mungkin itu” (I2).

2. Menjaga Saluran Air Subak

Berdasarkan hasil wawancara ditemukan fakta bahwa pihak pengelola Hidden Canyon menjaga saluran air subak di lokasi pertanian warga sekitar obyek wisata Hidden Canyon sebagai bentuk pelestarian lingkungan sebagaimana dinyatakan oleh I1 dan I2 sebagai berikut, "Jalur di persawahan ini yang kita pakai untuk aktivitas tracking, saluran airnya dijaga oleh satu orang pegawai yang tugasnya untuk membersihkan sampahnya saja" (I1). "Di hulu subak di sini kita juga menaruh satu karyawan yang tugasnya untuk membersihkan saluran air" (I2).

\section{Pembahasan}

Penelitian ini mengindikasikan bahwa pengelolaan obyek wisata Hidden Canyon memperhatikan keselarasan antara pengembangan ekonomi, kepedulian sosial dan pelestarian lingkungan. Aspek ekonomi merupakan salah satu aspek penting dalam pengelolaan obyek wisata berkelanjutan. Dalam aspek ekonomi, pihak pegelola berupaya untuk memberdayakan masyarakat lokal, meningkatkan daya tarik obyek wisata, dan memfasilitasi wirausaha lokal sehingga dapat memajukan perekonomian masyarakat lokal dan menambah daya tarik wisatawan untuk berkunjung ke obyek wisata Hidden Canyon. Selain aspek ekonomi, pihak pengelola juga memperhatikan aspek kepedulian sosial dengan memberi bantuan kepada desa adat dan bantuan dana keagamaan sehingga hubungan pihak pengelola dengan desa adat terjalin dengan baik. Dan yang terakhir yaitu aspek lingkungan yang selalu menjadi perhatian pihak pengelola dengan mengkampanyekan anti sampah plastik dan menjaga saluran air subak. Hal tersebut bertujuan agar lingkungan tetap bersih dan lestari sehingga wisatawan merasa nyaman saat berkunjung di obyek wisata Hidden Canyon.

Hasil penelitian ini selaras dengan pemikiran Azis (2019) mengenai prinsip sustainable development yang terdiri dari tiga aspek yaitu: 1. Aspek ekonomi, 2. Aspek sosial budaya dan 3. Aspek lingkungan. Aspek ekonomi yang dimaksud yaitu dengan pemberdayaan masyarakat, penerapan strategi peningkatan daya tarik obyek wisata dan yang terakhir yaitu memfasilitasi 
wirausaha lokal. Aspek sosial yang dimaksud yaitu pihak pengelola obyek wisata Hidden Canyon pada tahun 2019 memberikan bantuan sosial tunai kepada desa adat yang nantinya akan digunakan untuk pembangunan di Desa Guwang dan pihak pengelola juga memberi bantuan dana keagamaan ke pura-pura yang ada di Desa Guwang. Selanjutnya aspek lingkungan, hal yang dilakukan oleh pihak pengelola obyek wisata Hidden Canyon dalam pelestarian lingkungan yaitu salah satunya dengan cara mengkampanyekan dan mengimplementasikan gerakan anti sampah plastik dan pada hulu aliran air yang akan mengairi persawahan warga, pihak pengelola menugaskan salah satu karyawan untuk membersihkan saluran air tersebut dari sampah.

Penelitian ini senada dengan penelitian Qoriah et al. (2019) serta Adi \& Mulyadi (2019) yang juga menemukan tiga aspek utama dalam pengelolaan obyek wisata, yaitu aspek ekonomi, sosial budaya dan lingkungan atau kelestarian ekosistem. Lebih lanjut, Marasabessy et al. (2018) menemukan bahwa dalam pengelolaan wilayah pesisir dan laut Pulau Nusa Manu dan Pulau Nusa Leun di Kabupaten Maluku Tengah secara berkelanjutan, kriteria ekonomi, sosial budaya dan lingkungan dijadikan sebagai acuan penting. Dengan diperhatikannya aspek ekonomi, sosial budaya, dan lingkungan dalam pengelolaan obyek wisata, Dewi (2018) menemukan adanya dampak positif yang dirasakan, seperti meningkatnya pendapatan masyarakat, lingkungan obyek wisata terjaga dan lestari sesuai dengan karakteristik dan sosial budaya masyarakat, berlandaskan pada nilai-nilai kearifan lokal, sehingga tercapai kesejahteraan masyarakat. Sedikit berbeda dengan temuan penelitian ini dan penelitian lainnya, Nugroho et al. (2015) menemukan bahwa pihak pengelola hanya memperhatikan aspek ekonomi saja dalam pengelolaan obyek wisata, belum memperhatikan aspek sosial dan pelestarian lingkungan.

Dalam pengelolaan obyek wisata Hidden Canyon pihak pengelola menerapkan model pengelolaan berbasis nilai kearifan lokal tri hita karana yang selaras dengan prinsip sustainability. Hal tersebut bertujuan untuk menjaga keseimbangan hubungan antara manusia dengan Tuhan-Parahyangan, hubungan manusia dengan sesamanya-Pawongan dan hubungan manusia dengan lingkunganPalemahan. Hal serupa juga ditemukan oleh Lestari et al. (2017), nilai tri hita karana diaplikasikan dalam upaya konservasi subak dan lingkungan alam serta upaya menggali potensi subak sebagai daya tarik wisata.

Pengelola obyek wisata Hidden Canyon dalam penelitian ini sangat memperhatikan aspek ekonomi dalam pengembangan dan pengelolaan obyek wisata. Pihak pengelola berusaha untuk melibatkan seluruh masyarakat lokal dalam pengelolaan obyek wisata, antara lain dengan merekrut masyarakat lokal untuk bekerja di sana dan memfasilitasi masyarakat lokal untuk membuka kios di obyek wisata Hidden Canyon. Masyarakat yang saat ini bekerja sebagai pemandu di obyek wisata Hidden Canyon awalnya membuka usaha kecil-kecilan dengan memahat patung lalu menjualnya. Jumlah pendapatan dari usaha tersebut tidak menentu setiap bulannya karena tergantung pada penjualan patung. Banyak warga Desa Guwang yang kemudian memilih untuk bekerja sebagai pemandu di obyek wisata Hidden Canyon karena merasa memiliki pendapatan tetap setiap bulannya dan ditambah dengan tips atau bonus yang didapat dari tamu.

Sehingga, keadaan ekonomi mereka menjadi lebih baik setelah beralih profesi dari seorang pemahat menjadi pemandu obyek wisata. Tidak hanya pemandu wisata, masyarakat lokal yang difasilitasi untuk berdagang di obyek wisata Hidden Canyon juga merasa terbantu perekonomiannya karena sebelumnya mereka hanya membuka warung kecil di depan rumah. Penghasilan saat membuka warung di depan rumah tentu lebih sedikit karena jumlah pembeli yang tidak terlalu banyak, namun lain halnya saat mereka berjualan di obyek wisata Hidden Canyon, dimana banyak pembeli dari wisatawan yang berkunjung ke obyek wisata Hidden Canyon, 
sehingga pendapatan mereka juga meningkat. Bekerja sebagai pemandu dan pedagang di obyek wisata Hidden Canyon cukup membantu perekonomian karena ada penghasilan untuk membiayai pendidikan anak-anak mereka, kebutuhan rumah tangga sehingga manfaat dari pemberdayaan masyarakat lokal yaitu dapat meningkatkan taraf hidup masyarakat di Desa Guwang.

Harapan untuk kedepannya tidak hanya dapat meningkatkan taraf hidup masyarakat untuk saat ini namun juga untuk generasi mereka selanjutnya. Harapan serupa juga disampaikan oleh Arimbawa \& Santhyasa (2012), bahwa kesuksesan destinasi pariwisata dihasilkan dengan mempertahankan dan melestarikan sumber daya lokal sebagai katalis pembangunan kepariwisataan yang ada.

Hidden Canyon merupakan obyek wisata yang menawarkan keindahan alam sehingga pengelola obyek wisata Hidden Canyon tidak terlalu banyak melakukan perubahan terhadap bentang alami yang ada, namun tetap memperhatikan kelestariannya, seperti menjaga kebersihan di daerah aliran sungai dan menawarkan atraksi lain seperti hiking sambil menikmati suasana persawahan dari warga sekitar. Menjaga keasrian bentang alam sebagaimana aslinya sangatlah penting untuk meningkatkan daya tarik obyek wisata (Mahyuni, Permana, et al., 2020; Mahyuni, Yoga, et al., 2020).

Dalam pengelolaan obyek wisata Hidden Canyon, kegiatan pemasaran masih minim sehingga jumlah kunjungan wisatawan masih kurang maksimal. Kegiatan pemasaran untuk obyek wisata Hidden Canyon di media sosial Facebook dan Instagram masih kurang maksimal, yang terlihat dari jumlah postingan dengan jumlah like, comment dan share yang masih sedikit. Hal tersebut menjadi indikasi bahwa strategi pemasaran digital yang diterapkan masih belum optimal. Antusiasme warganet masih rendah dalam merespon informasi yang disampaikan obyek wisata Hidden Canyon. Pada tahun 2020, rata-rata jumlah like di media sosial Facebook hanya 10-30 likes, jumlah comment rata-rata hanya 10-20 comments, lalu jumlah share rata-rata hanya 10-20 per postingan. Pada media sosial Instagram jumlah like rata-rata sekitar 30-100 likes, lalu untuk comment di Instagram rata-rata sekitar 10 comments per postingan. Respon warganet di media sosial masih tergolong rendah. Strategi pemasaran digital pengelola obyek wisata Hidden Canyon masih perlu ditingkatkan untuk menarik minat lebih banyak wisatawan datang berkunjung. Contoh tangkapan layar upaya promosi melalui Facebook dan Instagram ditampilkan pada Gambar 1.
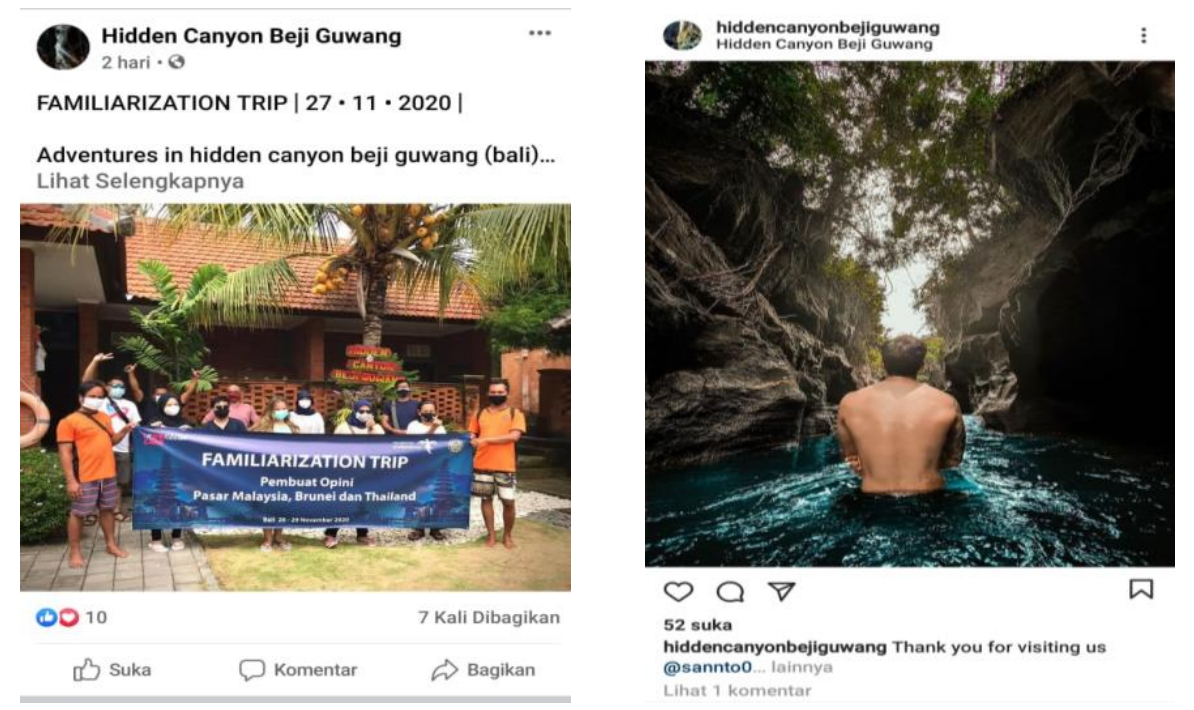

Gambar 1. Facebook dan Instagram Hidden Canyon 
Strategi pemasaran lainnya perlu dicoba untuk meningkatkan jumlah kunjungan wisatawan, seperti strategi promotional mix. Al-Bakry (2013) menemukan bahwa strategi yang tepat dan efesien untuk meningkatkan kunjungan wisatawan di obyek wisata Kebun Buah Mangunan adalah dengan menerapkan strategi promotional mix, yaitu: strategi advertising, sales promotion, personnal selling, dan publisitas. Dengan pengaplikasian strategi promotional mix dalam pemasaran obyek wisata Hidden Canyon diharapkan akan mampu untuk meningkatkan jumlah kunjungan wisatawan, baik lokal maupun mancanegara.

Strategi lain seperti strategi pemasaran word of mouth juga dapat diterapkan dalam pemasaran obyek wisata Hidden Canyon, karena tidak memerlukan biaya yang besar dalam penerapannya namun dirasa cukup efektif dalam meningkatkan jumlah kunjungan wisatawan. Mahyuni et al. (2020) menyatakan bahwa generasi milenial cenderung lebih mempercayai keluarga dan teman dekat dibandingkan pihak lain yang tidak mereka kenal, maka sangat penting menerapkan strategi pemasaran "word of mouth" atau promosi dari mulut ke mulut. Beberapa pendekatan dapat dilakukan untuk memotivasi generasi milenial yang sudah pernah berkunjung untuk menuliskan review positifnya dan merekomendasikan kepada keluarga dan teman dekat, antara lain dengan memberikan apresiasi berupa uang digital, potongan harga dan voucher belanja untuk kunjungan berikutnya, maupun insentif menarik lainnya.

Pengelola obyek wisata Hidden Canyon sangat memperhatikan aspek sosial dengan memberikan bantuan sosial kepada desa adat dan bantuan keagamaan. Bantuan sosial yang diberikan kepada masyarakat diperoleh dari pendapatan obyek wisata Hidden Canyon. Hal tersebut menunjukan bahwa pihak pengelola berusaha menjalin hubungan baik dengan masyarakat setempat. Berbeda dengan temuan penelitian ini, Darsana et al. (2017) menemukan bahwa pihak pengelola tidak memperhatikan hubungan dengan masyarakat setempat, melainkan hanya memperhatikan kepentingan dari investor untuk keperluan bisnis dan belum menunjukan ciri pariwisata berkelanjutan. Adanya kepedulian terhadap aspek sosial juga ditunjukkan dengan dibukanya lapangan kerja baru untuk masyarakat setempat, sehingga mampu meningkatkan taraf kehidupan, baik secara sosial maupun finansial.

Selain aspek ekonomi dan sosial, aspek lingkungan juga sama pentingnya dalam pengembangan obyek wisata Hidden Canyon. Pengelola memperhatikan aspek lingkungan dengan mengkampanyekan gerakan anti sampah plastik dan menjaga perairan subak sekitar agar tetap bersih dan lestari. Dalam penerapan aspek ekonomi dan sosial, pengelola Hidden Canyon melibatkan peran serta masyarakat, begitu pula dengan aspek lingkungan yang juga melibatkan peran serta masyarakat sekitar untuk menjaga kelestarian lingkungan. Pihak pengelola tidak hanya melibatkan karyawan dan wisatawan yang berkunjung untuk menjaga kelestarian lingkungan, tetapi juga melibatkan masyarakat sekitar. Keterlibatan masyarakat dalam pelestarian lingkungan yaitu dengan bersama-sama menjaga perairan subak agar tetap bersih dan selain itu masyarakat juga dihimbau untuk senantiasa menjaga kebersihan sepanjang aliran sungai dengan tidak membuang sampah di sungai agar tidak mengotori sungai sehingga wisatawan tetap merasa nyaman saat melakukan penyusuran sungai di Hidden Canyon. Menurut Adi \& Mulyadi (2019), kehadiran wisatawan menimbulkan tantangan tersendiri terkait upaya pelestarian lingkungan, sehingga partisipasi aktif masyarakat menjadi kekuatan yang menentukan dalam mewujudkan upaya pelestarian alam dan lingkungannya.

Meskipun dalam penelitian ini ditemukan bahwa pihak pengelola sangat memperhatikan aspek ekonomi, sosial, dan lingkungan sehingga dapat dikatakan memiliki kontribusi yang baik untuk masyarakat setempat dengan memberdayakan masyarakat lokal, akan tetapi masih ditemukan 
beberapa persoalan seperti kualitas SDM pengelola yang masih harus ditingkatkan, karena dalam sistem perekrutan, kompetensi pelamar tidak diperhatikan. Pihak pengelola langsung menerima calon pekerja tanpa adanya seleksi. Hal tersebut dibuktikan dari masih ditemukannya beberapa pemandu yang kurang menguasai Bahasa Inggris, sehingga terdapat kendala saat berkomunikasi dengan wisatawan asing.

Pengelola obyek wisata Hidden Canyon juga menghadapi persoalan pendanaan dalam pengembangan obyek wisata. Modal untuk pengembangan obyek wisata masih bergantung pada anggaran yang diberikan oleh pemerintah Desa Guwang setiap tahunnya, sehingga pengembangan untuk menambah sarana atraksi masih kurang maksimal. Selain itu, terdapat pula kendala saat musim hujan. Pada saat hujan wisatawan tidak dapat menelusuri Hidden Canyon, sementara tidak terdapat atraksi lain yang dapat dinikmati wisatawan, sehingga mengakibatkan wisatawan merasa kecewa saat berkunjung ke obyek wisata Hidden Canyon. Sehingga pada musim hujan obyek wisata Hidden Canyon sepi pengunjung dan tidak dapat beroperasi sebagaimana mestinya.

\section{KESIMPULAN DAN SARAN}

Penelitian ini mengidentifikasi adanya aplikasi model bisnis pengelolaan obyek wisata berbasis nilai kearifan lokal - tri hita karana dan sustainability. Terdapat tiga aspek utama yang dijalankan secara selaras dan bersama-sama, yaitu aspek keberlangsungan ekonomi, ekologi, dan sosial budaya, untuk tercapainya tujuan pengelolaan obyek wisata yang berkelanjutan. Ketiga aspek ini tidak dijalankan secara terpisah dan berdiri sendiri, melainkan saling terkait satu sama lain. Untuk menjamin keberlangsungan usaha dan meningkatkan kemampuan obyek wisata Hidden Canyon dalam meningkatkan kesejahteraan masyarakat (aspek ekonomi dan sosial), kelestarian lingkungan (aspek ekologi) dijaga dengan baik, karena hal ini disadari sebagai salah satu aspek penting daya tarik obyek wisata. Selain itu, dukungan akan aktivitas keagamaan, budaya dan sosial kemasyarakatan (aspek sosial budaya) juga diberikan secara penuh, selain untuk mendapatkan dukungan penuh masyarakat, juga untuk menunjang pembentukan daya tarik obyek wisata. Unsurunsur nilai kearifan lokal tri hita karana dijalankan dalam bentuk dukungan penuh pendanaan kegiatan keagamaan dan sosial budaya (parahyangan), komitmen mempekerjakan masyarakat lokal dan mendukung usaha masyarakat lokal (pawongan), serta komitmen menjaga kelestarian lingkungan alam (palemahan).

Dalam era digital ini, pengelola obyek wisata Hidden Canyon telah berupaya memanfaatkan berbagai saluran media sosial sebagai sarana promosi untuk meningkatkan jumlah kunjungan wisatawan, akan tetapi upaya ini masih belum optimal. Belum terlihat upaya untuk mendorong wisatawan yang berkunjung untuk membagikan pengalaman positifnya dalam bentuk video maupun foto-foto obyek wisata, maupun upaya untuk mengajak wisatawan melakukan subscribe pada berbagai saluran media sosial pengelola obyek wisata. Upaya mendorong keterlibatan lebih banyak dan jauh wisatawan dalam turut mempromosikan obyek wisata melalui media sosial sangatlah penting bagi upaya peningkatan jumlah kunjungan wisatawan. Upaya ini dapat ditempuh antara lain dengan memberikan berbagai insentif, seperti voucher pembelanjaan atau potongan harga untuk tiket masuk pada kunjungan berikutnya bagi wisatawan yang merekomendasikan kunjungan ke obyek wisata Hidden Canyon melalui berbagai saluran media sosial.

Sekalipun penelitian ini dilakukan pada satu obyek wisata di Bali, tidak tertutup kemungkinan temuan penelitian ini cukup relevan pula untuk diaplikasikan pada obyek wisata lain dengan konteks serupa. Nilai-nilai kearifan lokal daerah lain yang mendukung penerapan prinsip keberlanjutan dalam pengelolaan obyek wisata dapat pula digali lebih jauh dalam penelitian berikutnya pada konteks yang berbeda. 
MODEL PENGELOLAAN BISNIS OBYEK WISATA HIDDEN CANYON DI BALI Komang Aris Raharja et. al. BERBASIS KEARIFAN LOKAL TRI HITA KARANA DAN SUSTAINABILITY

\section{REFERENSI}

Adi, I. N. R., \& Mulyadi, M. (2019). Mediasi Community Based Tourism Pada Pengaruh Peran Desa Adat Terhadap Pembangunan Pariwisata Berkelanjutan Di Desa Penglipuran Kabupaten Bangli. Media Bina Ilmiah, 14(3), 2267. https://doi.org/10.33758/mbi.v14i3.331

Al-Bakry, M. H. N. (2013). Strategi Pemasaran Objek Wisata Kebun Buah Di Desa Mangunan Kecamatan Dlingo Kabupaten Bantul Untuk Meningkatkan Jumlah Kunjungan Wisatawan. Kepariwisataan: Jurnal Ilmiah, 7(1), 29-40.

Alfiah, S., Andriani, J., Lesmana, R., Sunardi, N., \& Furyanah, A. (2019). Manajemen Pengelolaan Desa Wisata Pada Desa Cimanggu, Kecamatan Cisalak, Kabupaten Subang, Provinsi Jawa Barat (Studi Kasus Pada Curug Paok dan Bukit Pasir Jaka). Abdi Masyarakat Humanis, 1(1), 21-28.

Anggreswari, N. P. Y., \& Jayaningsih, A. A. R. (2018). Pemberdayaan Masyarakat Melalui Pengembangan Objek Wisata Hidden Canyon Beji Guwang. Jurnal Ilmiah Ilmu Sosial, 4(1), 30-40. https://doi.org/10.23887/jiis.v4i1.13952

Apriyani, S. A. (2016). Strategi Badan Usaha Milik Desa Tirta Mandiri Dalam Pengelolaan Objek Wisata Umbul Ponggok Di Kecamatan Polanharjo Kabupaten Klaten. Jurnal Mahasiswa Ilmu Administrasi Negara Universitas Negeri Yogyakarta, 5(8), 1-11.

Dewi, A. A. I. Ari Atu (2018). Model Pengelolaan Wilayah Pesisir Berbasis Masyarakat: Community Based Development. Jurnal Penelitian Hukum De Jure, 18(2), 163. https://doi.org/10.30641/dejure.2018.v18.163-182

Arimbawa, W., \& Santhyasa, I. K. G. (2012). Model Pengelolaan Obyek Wisata Peninggalan Sejarah Taman Ayun Berbasis Nilai Lokal. Seminar Nasional Space \#3, 444-458.

Azis, I. J. (2019). PowerPoint: Living Standards \& Middle Income Trap: Indonesia's Challenges. Talk Show, Faculty of Economics.

Darsana, I. W., Sendra, I. M., Adikampana, I. M., \& Mahagangga, I. G. O. (2017). Model Pengelolaan Wisata Bahari Berkelanjutan Di Pulau Nusa Penida, Kecamatan Nusa Penida. Jurnal Analisis Pariwisata, 17(1), 10-16.

Dewi, M. H. U., Fandeli, C., \& Baiquni, M. (2013). Pengembangan Desa Wisata Berbasis Partisipasi Masyarakat Lokal di Desa Wisata Jatiluwih Tabanan, Bali. Jurnal Kawistara, $3(2), 117-226$.

Fauzi, A., \& Oxtavianus, A. (2014). The Measurement of Sustainable Development in Indonesia. Jurnal Ekonomi Pembangunan: Kajian Masalah Ekonomi Dan Pembangunan, 15(1), 6883. https://doi.org/10.23917/jep.v15i1.124

Gautama, I. G. O., \& Sunarta, N. (2016). Evaluasi Perkembangan Wisata Bahari di Pantai Sanur. In Jurnal Ilmiah Pariwisata (p. 5).

Haddouche, H., \& Salomone, C. (2018). Generation Z and the tourist experience: tourist stories and use of social networks. Journal of Tourism Futures, 4(1), 69-79. https://doi.org/10.1108/JTF-12-2017-0059

Hajian, M., \& Jangchi Kashani, S. (2021). 1 - Evolution of the concept of sustainability. From Brundtland Report to sustainable development goals (C. M. Hussain \& J. F. B. T.-S. R. M. Velasco-Muñoz (eds.); pp. 1-24). Elsevier. https://doi.org/https://doi.org/10.1016/B978-012-824342-8.00018-3

Haryanto, J. T. (2014). Model Pengembangan Ekowisata Dalam Mendukung Kemandirian Ekonomi Daerah Studi Kasus Provinsi Diy. Jurnal Kawistara, 4(3). https://doi.org/10.22146/kawistara.6383

Hidayat, M. (2011). Strategi Perencanaan dan Pengembangan Objek Wisata (Studi Kasus Pantai Pangandaran Kabupaten Ciamis Jawa Barat). Tourism and Hospitality Essentials (THE) Journal, I(1), 33-44. 
Juniari, N. W., \& Mahyuni., L. P. (2020). Implementasi Corporate Social Responsibility (CSR) dalam Mewujudkan Pariwisata Berbasis Masyarakat Berkelanjutan. Jurnal Muara Ilmu Ekonomi Dan Bisnis, 4(1). https://doi.org/DOI: http://dx.doi.org/10.24912/jmieb.v4i1.7449

Kemenpar. (2020). Penyerapan tenaga kerja sektor pariwisata, 2010-2019. https://lokadata.id/data/penyerapan-tenaga-kerja-sektor-pariwisata-2010-2019-1582009409

Krishna, A. (2010). The Wisdom of Bali The Sacred Science of Creating Heaven on Earth. Gramedia Pustaka Utama.

Kristiana, Y. (2019). Buku Ajar Studi Ekowisata. CV Budi Utama.

Kurniawati, R. (2013). Modul Pariwisata Berkelanjutan.

Laksana, S. D. (2020). Tumpuk Pesona. Unmuh Ponorogo Press.

Lestari, N. P. N. E., Sunia, W., \& Wijayanthi, N. W. (2017). Empowerment of " Subak " in Development of Sustainable Eco-Tourism Village in Bali Indonesia. International Journal of Economics, Commerce and Management, 5(6), 796-810.

Mahadewi, N. P. E., \& Sudana, I. P. (2017). Model Strategi Pengembangan Desa Wisata Berbasis Masyarakat Di Desa Kenderan Gianyar Bali. Analisis Pariwisata, 17(1), 41-45.

Mahyuni, L. P., \& Dewi, I. G. A. A. T. (2021). CORPORATE SOCIAL RESPONSIBILITY, KEARIFAN LOKAL 'TRI HITA KARANA', DAN PARIWISATA BERBASIS MASYARAKAT BERKELANJUTAN. Jurnal Ilmiah Ekonomi Dan Bisnis, 17(2), 99-105.

Mahyuni, L. P., Permana, G. P. L., Yoga, I. M. S., \& Setiawan, I. W. A. (2020). Bisnis Eco-Park Di Mata Milenial: Eksplorasi Persepsi Dan Intensi Milenial Mengunjungi Eco-Park. Ekonomi Dan Bisnis, 7(1), 75. https://doi.org/10.35590/jeb.v7i1.1689

Mahyuni, L. P., Yoga, I. M. S., Permana, G. P. L., \& Setiawan, I. W. A. (2020). Bagaimana Bisnis Eco-Park Menarik Minat Milenial? Sebuah Model Untuk Memahami Intensi Milenial Mengunjungi Eco-Park. Forum Ekonomi, 22(2), 218-231.

Marasabessy, I., Fahrudin, A., Imran, Z., \& Agus, S. B. (2018). Strategi Pengelolaan Berkelanjutan Pesisir dan laut Pulau Nusa Manu dan Nusa Leun di Kabupaten Maluku Tengah. Journal of Regional and Rural Development Planning, 2(1), 1-22. https://doi.org/10.29244/jp2wd.2018.2.1.11-22

Novarini, N. N., \& Anggraini, N. P. N. (2017). Analisis Pengaruh Kualitas Layanan, Citra, dan Promosi Terhadap Tingkat Kepuasan Pengunjung Pada Hidden Canyon Beji Guwang. Forum Manajemen, 15(2), 110-117.

Nugroho, J. W., Gandasasmita, K., \& Manuwoto. (2015). Arahan Pengembangan Obyek Wisata Menuju Pembangunan Pariwisata Berkelanjutan Di Kabupaten Wonogiri. Jurnal Kawistara, 5(3), 221-328. https://doi.org/10.22146/kawistara.10053

Pratiwi, N., Santosa, D. B., \& Ashar, K. (2018). Analisis Implementasi Pembangunan Berkelanjutan Di Jawa Timur. Jiep, 18(1), 1-13.

Putra, H. G., \& Putra, I. (2019). Pengembangan Objek Wisata Berwawasan Lingkungan Hidup : (Studi Objek Wisata Puncak Tonang Nagari Sundata Kabupaten Pasaman). Journal of Civic Education, 2(5), 459-467.

Qoriah, D., Ungkari, M. D., \& Muharam, H. (2019). Pengembangan Pariwisata Berkelanjutan Wisata Domba Adu di Desa Rancabango Tarogong Kaler Garut. Journal Of Knowledge Management, 13(2), 1-10. https://doi.org/10.1016/j.tmp.2019.06.002

Rosana, M. (2018). Kebijakan Pembangunan Berkelanjutan Yang Berwawasan Lingkungan di Indonesia. KELOLA Jurnal Ilmu Sosial, 1(1), 148-163.

Sembiring, J. P. (2016). Strategi Komunikasi Pemasaran Objek Wisata Gundaling dan Pemandian Air Panas Semangat Gunung. Jurnal Simbolika, 2(1), 1-22.

Sumaeni, N. M., \& Mahagangga, I. G. A. O. (2018). Sistem Pengelolaan Terhadap Pura Tirta Empul Sebagai Daya Tarik Wisata Pusaka Di Tampak Siring Gianyar. Jurnal Destinasi Pariwisata, 5(2), 322-326. https://doi.org/10.24843/jdepar.2017.v05.i02.p22 
Wisata, K. P. O. (2020). Data Pengunjung Obyek Wisata Hidden Canyon Desa Guwang Tahun 2017 - 2019.

Wisnawa, I. M. B., Prayogi, P. A., \& Sutapa, I. K. (2019). Manajemen Pemasaran Pariwisata Model Brand Loyalty Pengembangan Potensi Wisata di Kawasan Pedesaan. CV Budi Utama.

Wiweka, K., Wachyuni, S. S., Rini, N. A., Adnyana, I. N., \& Adnyana, P. P. (2019). PERILAKU BERWISATA WISATAWAN GENERASI MILENIAL DI JAKARTA PADA ERA REVOLUSI INDUSTRI 4.0. Jurnal Sains Terapan Pariwisata, 4(3), 313-334.

Yachya, A. N., Wilopo, \& Mawardi, M. K. (2016). Pengelolaan Kawasan Wisata Sebagai Upaya Peningkatan Ekonomi Masyarakat Berbasis CBT (Community Based Tourism). Jurnal Administrasi Bisnis, 39(2), 107-116. 